\title{
Efektivitas Penggunaan Media Online Tirto.Id terhadap Pemenuhan Kebutuhan Informasi Berita Livi Zheng
}

\author{
Mesi Indriyani, A.A Bambang, Dian Tri Hapsari \\ Universitas Pembangunan Nasional "Veteran" Jakarta \\ indri.mesi@gmail.com \\ aa_saputera2@hotmail.com \\ diantrihapsari@upnvj.ac.id
}

\begin{abstract}
Abstrak
Perkembangan teknologi mendorong masyarakat lebih aktif serta selektif untuk mencari informasi berita di internet. Lama penggunaan internet di Indonesia terdiri dari $14,1 \%$ selama 3 - 4 jam, 13,4 \% selama $2-3$ jam, serta $13 \%$ selama $1-2$ jam. Indonesia memiliki 43 ribu portal berita online, namun yang terverifikasi tidak lebih dari 100 media, yang menyebabkan banyak informasi cukup beragam tersebar di media internet. Salah satunya media online di Indonesia yakni tirto.id yang memanfaatkan data berupa foto, kutipan, rekaman peristiwa serta data statistik yang ditampilkan lewat tulisan, infografik dan video infografik. Penelitian ini menjelaskan bagaimana efektivitas penggunaan media tirto.id terhadap pemenuhan kebutuhan infomasi berita Livi Zheng. Tujuan penelitian ini untuk mengetahui berefek atau tidaknya penggunaan media online sebagai pemenuhan kebutuhan informasi berita Livi Zheng. Penelitian ini menggunakan teori Uses and Gratification, dengan metode kuantitatif. Hasil penelitian menunjukkan bahwa hasil uji korelasi variabel X (Penggunaan media online tirto.id) terhadap variabel $\mathrm{Y}$ (pemenuhan kebutuhan informasi) sebesar 0,451. Berdasarkan hasil perhitungan koefisien determinasi didapatkan hasil 20,3\%. Hasil uji t didapatkan $\mathrm{t}$ hitung $>\mathrm{t}$ tabel yaitu $\mathrm{t}$ hitung 4,715 > tabel 1,662, maka dapat disimpulkan Ho ditolak dan Ha diterima. Kesimpulan penelitian ini, terdapat hubungan yang tidak terlalu signifikan antara variabel $\mathrm{X}$ (penggunaan media online) terhadap variabel Y (pemenuhan kebutuhan informasi). Saran dari penelitian ini, media tirto.id bisa memberikan kebutuhan informasi lebih kuat dalam mengangkat suatu pemberitaan. Sehingga pembaca dapat memahami lebih baik atas topik pemberitaan yang diangkat.
\end{abstract}

Kata kunci : Uses and Gratification, Penggunaan Media, Media Online

Permalink/DOI: http://doi.org/10.15408/jsj.v2i2.15065 


\section{Pendahuluan}

Perkembangan teknologi memudahkan masyarakat mencari berita, hal ini mendorong masyarakat untuk lebih efektif dan selektif dalam mencari berita. Internet berkembang menjadi teknologi yang tidak hanya mampu mentransmisikan berbagai informasi, namun mampu menciptakan dunia baru dan realitas kehidupan manusia. Menurut Bungin (2006: 136) internet adalah bentuk konvergensi dari beberapa teknologi penting terdahulu seperti komputer (dengan berbagai varian manfaat), televisi, radio, dan telepon (Bungin, Burhan. 2006: 136). Menurut Koyo, Mori dan Takano dalam Sultoni (2013: 23) keistimewaan yang terdapat dalam internet, pertama bersifat bebas, kedua internet lebih dinamis dengan mengikuti perkembangan waktu, ketiga bersifat interaktif (Violita. 2016: 15).

Menurut temuan katadata.com data statista 2019 menunjukkan penggunaan internet di Indonesia tahun 2018 sebanyak 95,2 juta dengan jumlah pertumbuhan 13,3\% dari tahun 2017 yang sebanyak 84 juta pengguna. Tahun 2019 jumlah pengguna internet mencapai 12,6\% dibanding tahun 2018 yaitu 107,2 juta pengguna (katadata.com. 2019). Data survei lama pengguna internet yang dilakukan APJII (Asosiasi Penyelenggara Jasa Internet Indonesia) sebanyak 14,1\% dari 3 - 4 jam, 13,4\% dari 2 - 3 jam, serta 13\% dari 1 - 2 jam (APJII. 2018). Melalui data tersebut menunjukkan masyarakat memanfaatkan penggunaan internet dalam kehidupannya.

Menurut Menteri Komunikasi dan Informatika Rudiantara, di Indonesia terdapat 43 ribu portal berita online, namun jumlah terverifikasi Dewan Pers tidak lebih 100 media (Kominfo. 2018).
Fenomena ini menunjukkan media online yang ada cukup banyak menyebabkan banyak informasi yang cukup beragam tersaji di media online, salah satunya media tirto.id. Salah satu berita yang menarik dalam media tirto.id yakni mengenai Livi Zheng. Nama Livi Zheng menjadi perbincangan lantaran klaim dirinya telah berhasil dalam dunia perfilman internasional dan karyanya masuk dalam nominasi Oscar. Artikel yang ditulis tagar.id menjelaskan kontroversi Livi Zheng bermula namanya dibahas media tanah air karena karyanya disebut menembus Hollywood. Berdasarkan hal tersebut, apakah penggunaan media online tirto.id sudah efektif dalam memenuhi kebutuhan informasi kepada masyarakat terutama mahasiswa mengenai pemberitaan terkait Livi Zheng.

\section{Tinjauan Pustaka \\ Efektivitas}

Efektivitas umumnya memiliki hubungan antara hasil yang diharapkan dengan kenyataan hasil yang telah dicapai. Menurut Sedarmayanti (2009: 59), efektivitas merupakan ukuran yang memberikan gambaran seberapa jauh target dapat dicapai (Riyantini. 2015: 3). Target tercapai penelitian ini yakni penggunaan media untuk memenuhi kebutuhan informasi. Ketika pengguna sudah efektif berarti khalayak yang menggunakan media termasuk target sasaran media, baik tampilan ataupun isi yang disajikan.

\section{Media Online}

Menurut Suryawati (2011: 46) media online merupakan media komunikasi yang pemanfaatannya menggunakan perangkat internet. Media 
online tergolong media bersifat khas, terletak pada penggunaan perangkat komputer di samping pengetahuan tentang program komputer untuk mengakses informasi atau berita (Suryawati. 2011: 46). Menurut Santana, Septiawan (2005: 138) internet adalah jurnalisme yang berubah. Perubahanperubahan yang dibawa kemungkinan teknologis mengartikulasikan kembali peranan-peranan dan fungsi-fungsi profesi ini. Sebuah studi Singer (2001) bahwa ketika surat kabar menjadi online, peran penjaga gerbang (gatekeeper) menghilang. Menurut Straubhar dan LaRose (2000: 267), pengguna internet menggantungkan pada situs untuk memperoleh data. Dua sampai tiga pengguna internet mengakses situs untuk mendapatkan berita terbaru setiap minggunya (Ardianto. 2007: 149).

\section{Media Online Tirto.id dalam Memberitakan Livi Zheng}

Tirto.id adalah situs berita, artikel, opini dan infografik di Indonesia yang muncul pada Februari 2016 dan diresmikan 3 Agustus 2016. Memiliki slogan "Jernih, Mengalir, Mencerahkan", media tirto.id memanfaatkan data berupa foto, kutipan, rekaman peristiwa serta data statistik. Produk-produk jurnalisme yang disajikan dilengkapi hasil analisis ratusan media dari seluruh Indonesia yang disarikan dalam bentuk tiMeter (pengukuran sentimen) atas tokoh, lembaga, serta kasus yang dibicarakan tiap laporan mendalam.

Media tirto.id salah satu media yang memberitakan mengenai Livi Zheng dan telah memuat sebanyak 13 berita. Livi Zheng adalah seorang sutradara perempuan yang mempunyai nama lengkap Livia Notoharjono lahir di Blitar, Jawa Timur 3 April 1989. Melalui artikel yang diterbitkan detikhot, ia besar di keluarga pebisnis. Namanya menjadi ramai diperbincangkan karena klaim "keberhasilannya" sebagai sutradara perempuan muda di kancah perfilman internasional. Film yang berjudul Brush with Danger dan Bali: Beats of Paradise produksi Sun and Moon Films yang berbasis di Amerika Serikat.

Opini mengenai Livi Zheng menjadi viral di media sosial twitter dan masuk ke dalam trending twitter Indonesia. Setelah menjadi viral warganet justru merundung dan menganggap telah berbohong perihal klaim-klaim prestasi yang ternyata semu. Isi dari pemberitaan mengenai Livi Zheng di media tirto.id lebih membahas mengenai siapa sosok Livi Zheng, kebenaran dari klaim film karya Livi Zheng yang viral dikatakan masuk ke dalam nominasi Oscar serta sisi keluarga Livi Zheng.

\section{Penggunaan Media}

Menurut Poedarminta (1976: 332) penggunaan yakni kaedah, manfaat, suatu perbuatan yang memberikan pengaruh mendatangkan perubahan arti. Penggunaan menurut Poerwadarminta (dalam KUBI 1976: 33) diartikan sebagai suatu hal atau perbuatan dalam menggunakan sesuatu. Misalnya untuk kepentingan umum atau kepentingan pribadi. Dalam penelitian ini mengacu kepada penggunaan media sebagai suatu hal atau perbuatan dalam memanfaatkan sesuatu (menggunakan media) untuk kepentingan dirinya dalam hal ini kepentingan memenuhi kebutuhan informasi mengenai pemberitaan Livi Zheng. 
Dimensi penggunaan media menurut Rosengren dalam Rakhmat (2005: 67) terbagi menjadi: jumlah waktu yang digunakan dalam berbagai media (frekuensi dan durasi penggunaan), jenis isi media yang dikonsumsi (isi pesan) dan berbagai hubungan media secara keseluruhan. Hubungan antar khalayak dengan isi media melalui attention atau perhatian pada isi media tersebut. Menurut Kenneth E. Andersen (dlaam Dwipuspita. 2012: 9) mendefinisikan perhatian sebagai proses rangkaian stimuli menjadi menonjol dalam kesadaran pada saat stimuli lain melemah. Adapun sifat yang menonjol dari yang kita perhatiakan dalam menggunakan media adalah pada tampilan media (Violita. 2016: 23).

Frekuensi menurut Ardianto
(2004: 164) adalah banyaknya
pengulangan perilaku yang menjadi target
(seringnya kegiatan itu dilaksanakan dalam periode waktu tertentu). Dalam penelitian ini pada aktivitas akses internet atau media online (berapa kali dalam sehari, seminggu, sebulan). Sementara durasi yakni curahan waktu yang dibutuhkan dalam mengkonsumsi suatu media atau lamanya selang waktu yang dibutuhkan untuk menggunakan internet (berapa jam sehari atau berapa menit).

\section{Teori Uses and Gratification}

Teori yang akan digunakan dalam penelitian ini adalah Teori Uses and Gratification yang pertama kali diperkenalkan oleh Elihu Katz, jay G. Blumber dan Michael Gurevitch (1974). Teori ini tidak tertarik dengan yang dilakukan media pada seseorang tapi pada yang dilakukan orang terhadap media (Jalaluddin. 1984). Menurut Blumer dan
Katz, teori uses and gratifications mengansumsikan bahwa pengguna mempunyai pilihan alternatif untuk memuaskan kebutuhannya (Nurudin. 2017: 192). Memusatkan perhatian pada penggunaan (uses) media untuk mendapatkan pemenuhan (gratification) atas kebutuhan seseorang. Oleh karena itu sebagian besar perilaku khalayak akan dijelaskan melalui berbagai kebutuhan (needs) dan kepentingan individu.

$$
\text { Uses and gratifications }
$$
menunjukkan bahwa yang menjadi permasalahan utama bukanlah bagaimana media mengubah sikap dan perilaku khalayak tetapi bagaimana media memenuhi kebutuhan pribadinya dan sosial. Katz dan kawan-kawan (1974) dan Denic McQuail (1975) menggambarkan logika yang mendasari penelitian terhadap uses and gratification sebagai berikut :

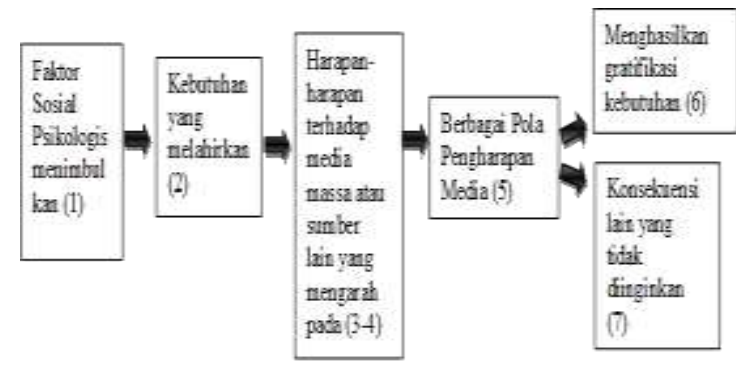

Unsur-unsur uses and gratification diatas bila dikaitkan dengan masalah pokok penelitian menjadi faktor sosial psikologis menimbulkan keinginan membaca tirto.id, sehingga keinginan tersebut hadir dari suatu kebutuhan pengetahuan, perasaan dan perilaku terhadap penggunaan media online tirto.id. Melahirkan harapan-harapan terhadap media massa yang mengarah pada media tirto.id memenuhi kebutuhan informasi pembaca.

Menimbulkan pola pengharapan seperti pengetahuan bertambah, sikap dan perilaku menjadi lebih pasti setelah 
membaca informasi dan berita. Bisa pula menghasilkan konsekuensi yang tidak diinginkan seperti tidak terpenuhinya kebutuhan informasi dari media tirto.id. Model-model kegunaan dan gratifikasi dirancang untuk menggambarkan proses penerimaan dalam komunikasi massa dan menjelaskan penggunaan media oleh individu atau kelompok-kelompok individu.

Dapat dikatakan bahwa yang menjadi alasan mengapa khalayak menggunakan media adalah kondisi sosial psikologis yang dirasakan sebagai sebuah masalah oleh khalayak dan media digunakan untuk mengatasi berbagai masalah tersebut. Menurut Jay G. Blumber (1979) yang di maksud dengan khalayak aktif adalah :

1. Utility atau penggunaan - media digunakan khalayak dan khalayak dapat menempatkan media ke dalam berbagai fungsi penggunaan.

2. Intentionally atau kesengajaan motivasi utama khalayak dalam mengkonsumsi media.

3. Selectivity atau seletivitas penggunaan media oleh anggota khalayak merefleksikan adanya minat dan prefensi.

4. Imperviousness to influence atau ketahanan terhadap pengaruh anggota khalayak membentuk arti sendiri terhadap isi yang kemudian mempengaruhi apa yang ia pikirkan dan lakukan. Mereka dapat menghindari berbagai macam pengaruh media.

Menurut Katz, Elihu dan Blumer (1974) kebutuhan tertentu individu meliputi: kebutuhan kognitif, kebutuhan afektif, integrasi personal, integrasi sosial, dan untuk pelarian (escapist). Sementara lingkungan sosial yang mempengaruhi kebutuhan tadi yaitu berupa ciri-ciri demografis, afiliasi kelompok dan ciri-ciri individu (Imran. 2013: 3). Sedangkan kebutuhan khalayak dapat digolongkan menjadi lima:

1. Kognitif, kebutuhan yang berkaitan dengan peneguhan informasi, pengetahuan, dan pemahaman mengenai lingkungan. Contoh: televisi (menonton berita), film (dokumenter).

2. Afektif, kebutuhan yang berkaitan dengan penugahan pengalaman yang estesis, menyenangkan dan emosional. Contoh: televisi (komedi situasi, drama).

3. Integrasi Personal, kebutuhan yang berkaitan dengan peneguhan kredibilitas, kepercayaan, stabilitas dan status individual. Contoh: video ("bagaimana berbicara dengan keyakinan").

4. Integrasi Sosial, kebutuhan yang berkaitan dengan peneguhan kontak dengan keluarga, teman dan dunia. Hal tersebut didasarkan hasrat untuk berafiliasi. Contoh: internet (email, chat room, dll).

5. Pelepasan ketegangan, berkaiatan dengan kebutuhan menghindarkan tekanan, ketegangan, dan hasrat akan keanekaragaman. Contoh: televisi, radio, video, internet.

\section{Metode}

Penelitian ini menggunakan jenis penelitian kuantitatif dengan metode survei. Menurut Faisal (2003: 23) dengan survei peenliti menggambarkan karakteristik tertentu dari suatu populasi, 
apakah berkenaan dengan sikap, tingkah laku, ataupun aspek sosial lainnya; variabel yang ditelaah disejalankan dengan karakteristik yang menjadi fokus penelitian tersebut (Ardial. 2015: 264). Untuk mendapatkan data tersebut penulis menggunakan kuesioner yang disebarkan lalu data tersebut diukur sehingga diidentifikasikan hubungan antara variabel.

Penelitian ini menggunakan jenis penelitian ekplanatif untuk menemukan penjelasan. Menurut Faisal (2001: 21-22) penelitian eksplanasi adalah penelitian untuk menguji hubungan antarvariabel yang dihipotesiskan. Hipotesis tersebut menggambarkan hubungan antara dua atau lebih variabel. Untuk mengetahui apakah suatu variabel berasosiasi atau tidak dengan variabel lainnya atau suatu variabel disebabkan atau dipengaruhi atau tidak oleh variabel lainnya (Goenawan. 2016: 50).

\section{Hasil dan Pembahasan}

Berdasarkan data yang telah diolah dari sejumlah populasi penelitian adalah mahasiswa ilmu komunikasi, diketahui jumlah mahasiswa ilmu komunikasi angkatan 2016 berjumlah 236, angkatan 2017 berjumlah 247, angkatan 2018 berjumlah 299 dengan total 779 populasi. Menentukan jumlah sampel peneliti menggunakan teknik probability sampling dengan teknik simple random sampling yakni teknik sampling yang memberikan peluang sama bagi setiap unsur (anggota) populasi untuk dipilih menjadi sampel. Dilakukan secara acak tanpa memerhatikan strata yang ada dalam anggota populasi.

Untuk mengukur sampel, penulis menggunakan rumus Slovin dengan batas error 10\%. Dari jumlah 779 orang, dihasilkan sampel sebesar 88,62, maka jika dibulatkan dipilih 89 orang sampel, dengan menggunakan rumus :

$$
n=\frac{N}{1+\mathrm{Ne}^{2}}
$$

Keterangan:

$\mathrm{n}=$ ukuran sampel

$\mathrm{N}=$ ukuran populasi

e = kelonggaran ketidaktelitian karena

kesalahan pengambilan sampel yang dapat ditolerir. Pada penelitian ini menggunakan nilai ketidaktelitian sebesar $10 \%$

$$
\begin{gathered}
n=\frac{N}{1+N e^{2}} \\
n=\frac{779}{1+779(10 \%)^{2}} \\
n=\frac{779}{1+779(0,1)^{2}} \\
n=\frac{779}{1+779(0,01)} \\
n=\frac{779}{8,79} \\
n=88,62(89)
\end{gathered}
$$

Untuk menghitung jumlah responden dari ketiga angkatan tersebut secara acak, ditentukan dan dihitung dengan rumus sebagai berikut:

$$
n i=\frac{N i}{\mathrm{~N}} n
$$

Keterangan:

$n i$ : jumlah anggota sampel menurut stratum

$n$ : jumlah angota sampel seluruhnya

$N i$ : jumlah anggota populasi menurut stratum

$\mathrm{N}$ : jumlah anggota populasi seluruhnya

\begin{tabular}{|c|c|c|}
\hline $\begin{array}{c}\text { Tahun } \\
\text { Angkatan }\end{array}$ & $\begin{array}{c}\text { Jumlah } \\
\text { Mahasiswa }\end{array}$ & $\begin{array}{c}\text { Perhitungan } \\
\text { Responden }\end{array}$ \\
\hline
\end{tabular}




\begin{tabular}{|c|c|c|}
\hline 2016 & 236 & $\begin{array}{l}n i=\frac{236}{779} 89 \\
=0,383 \mathrm{x} \\
89 \\
=26,9(27)\end{array}$ \\
\hline 2017 & 247 & $\begin{array}{l}n i=\frac{247}{779} 89 \\
=0,317 \mathrm{x} \\
89 \\
\quad=28,21 \\
(28)\end{array}$ \\
\hline 2018 & 299 & $\begin{array}{l}n i=\frac{299}{779} 89 \\
=0,383 \mathrm{x} \\
89 \\
=34,1(34)\end{array}$ \\
\hline
\end{tabular}

Penyebaran kuesioner dilakukan dengan menyebar secara acak kepada mahasiswa ilmu komunikasi sesuai kriteria dan jumlah yang telah ditentukan. Kuesioner yang sudah diisi dan mancapai target yang diperlukan dalam penelitian ini dapat langsung diolah untuk mengetahui hasilnya. Proses analisis data dilakukan menggunakan program windows statistic for social science (SPSS) versi 26.

Analisis data pertama yakni analisis korelasi, yaitu analisis yang mengukur tingkat hubungan antara dua variabel, variabel bebas (independent variabel) dan variabel terikat (dependent variabel).

\section{Correlations}

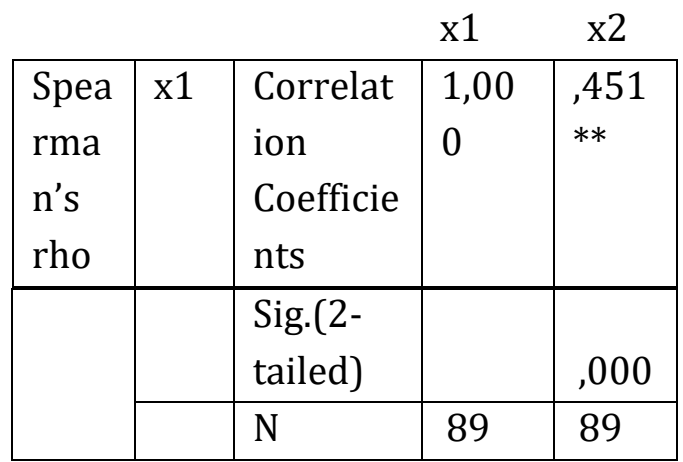

\begin{tabular}{|l|l|l|l|l|}
\hline & y1 & $\begin{array}{l}\text { Correlat } \\
\text { ion } \\
\text { Coefficie } \\
\text { nt }\end{array}$ & $\begin{array}{l}, 451 \\
* *\end{array}$ & $\begin{array}{l}1,00 \\
0\end{array}$ \\
\cline { 2 - 5 } & $\begin{array}{l}\text { Sig.(2- } \\
\text { tailed) }\end{array}$ &, 000 & \\
\cline { 2 - 4 } & $\mathrm{N}$ & 89 & 89 \\
\hline
\end{tabular}

Ditemukan hubungan kedua variabel sebesar 0,451 yaitu hubungan yang sedang karena terletak antara tingkat korelasi 0,41 - 0,60. Hal ini belum mencapai hubungan yang kuat karena tidak semua pembaca tirto.id membaca pemberitaan mengenai Livi Zheng. artinya khalayak telah memanfaatkan media online dengan cukup baik dalam mencari informasi walaupun belum mencapai hasil yang maksimal.

Analisis data kedua yakni analisis koefisien determinasi, menjelaskan besarnya kontribusi yang diberikan variabel independen terhadap variabel dependen, dihitung dengan rumus sebagai berikut:

$$
\mathrm{Kd}=\mathrm{r}^{2} \times 100 \%
$$

\section{Keterangan :}

Kd : Koefisien Determinasi

r $\quad$ : Koefisien Korelasi

$\mathrm{Kd}=\mathrm{r}^{2} \times 100 \%$

$\mathrm{Kd}=0,451^{2} \times 100 \%$

$\mathrm{Kd}=0,203 \times 100 \%$

$\mathrm{Kd}=20,3 \%$

Melalui rumus tersebut ditemukan bahwa efektivitas penggunaan media online tirto.id terhadap pemenuhan kebutuhan informasi sebesar 20,3\% sedangkan sisanya sebesar 79,7\% disebabkan oleh faktor lain yang tidak diteliti dalam penelitian. Maka dapat disimpulkan bahwa tidak semua pembaca 
media tirto.id akan membaca berita Livi Zheng karena isu kontroversi tentang dirinya atau rasa penasaran mengenai siapa sosok Livi Zheng.

Analisis data ketiga yakni analisis hipotesis peneliti menggunakan uji $\mathrm{T}$ untuk menentukan uji $\mathrm{T}$ penelitian ini menggunakan cara manual dengan rumus:

$$
\mathrm{t}=\frac{r \sqrt{n-2}}{\sqrt{1-r 2}}
$$

Keterangan :

r: korelasi

$\mathrm{n}$ : jumlah Responden $(\mathrm{n}-2=\mathrm{dk}$, derajat kebebasan)

$$
\begin{aligned}
& \mathrm{t}=\frac{r \sqrt{n-2}}{\sqrt{1-r^{2}}} \\
& \mathrm{t}=\frac{0,451 \sqrt{89-2}}{\sqrt{1-0,451^{2}}} \\
& \mathrm{t}=\frac{0,451 \sqrt{87}}{\sqrt{1-0,203}} \\
& \mathrm{t}=\frac{0,451 \times 9,327}{\sqrt{0,797}} \\
& \mathrm{t}=\frac{4,206}{0,892} \\
& \mathrm{t}=4,715
\end{aligned}
$$

Hasil uji hipotesis atau uji $\mathrm{T}$ memperoleh t hitung sebesar 4,715. Dari hasil korelasi antara variabel $\mathrm{x}$ (penggunaan media online tirto.id) dengan variabel y (pemenuhan kebutuhan informasi) $\mathrm{t}$ hitung 4,71 > t tabel 1,662 maka didapatkan Ho ditolak dan $\mathrm{Ha}$ diterima. Artinya penggunaan media online tirto.id cukup efektif dalam memenuhi kebutuhan informasi mengenai pemberitaan Livi Zheng di media terlihat dari respon sebagai media dalam memenuhi kebutuhan informasi.

Penelitian ini sesuai dengan teori uses and gratification di mana khalayak aktif memilih media yang memenuhi kebutuhannya. Serta dari penggunaan media dapat diasumsikan media tirto.id cukup untuk memenuhi kebutuhan informasi akan keingintahuan pemberitaan Livi Zheng. teori uses and gratification digunakan dalam penelitian untuk melihat audiens menggunakan suatu media dalam pemenuhan kebutuhannya, sudah tercukupi atau belum serta efektif dalam menggunakan media tersebut.

Penggunaan media terdiri atas jumlah waktu yang dihabiskan untuk menggunakan media online tirto.id mencari dan membaca berita di dalam unggahannya. Isi media tirto.id yang dilihat pada topik pemberitaan yang telah di unggah media tirto.id. Kejelasan dalam membahas topik pemberitaan serta adanya kelengkapan atas sumber maupun data pendukung di setiap informasi dan berita yang diangkat. Serta tampilan akan suatu media yang dilihat atas kemudahannya, fitur-fitur yang terdapat dalam media seperti fitur berbagi link berita ke media sosial, fitur pencarian topik pemberitaan yang akan dicari. Hasil ini menunjukkan bahwa penggunaan media tirto.id harus bisa memberikan kebutuhan informasi lebih baik kepada pembaca atas setiap pembahasan yang diangkat.

\section{Penutup}

\section{Kesimpulan}

Penelitian ini dilakukan untuk mengetahui besarnya hubungan penggunaan media online tirto.id dengan pemenuhan kebutuhan informasi mengenai pemberitaan Livi Zheng. Berdasarkan hasil penelitian yang didapatkan melalui penyebaran kuesioner dan survei yang dilakukan kepada 89 orang sampel, selanjutnya data tersebut diolah dengan menggunakan beberapa uji penelitian. Pertama uji korelasi sebesar 0,451 , nilai ini memiliki hubungan yang 
cukup karena terletak diantara 0,40 - 0,60. Berdasarkan hasil uji koefisien determinasi sebesar 20,3\% sedangkan sisanya sebesar 79,7\% dipengaruhi faktor lain di luar variabel $\mathrm{x}$ dan variabel y yang tidak diteliti dalam penelitian. Maka dapat disimpulkan tidak semua pembaca tirto.id membaca pemberitaan Livi Zheng.

Hasil hipotesis didapatkan bahwa $t$ hitung $(4,71)>t$ tabel $(1,662)$ maka Ho ditolak dan $\mathrm{Ha}$ diterima. Artinya efektivitas penggunaan media online tirto.id masuk dalam kategori cukup efektif dalam memenuhi kebutuhan mengenai pemenuhan informasi terkait Livi Zheng. Penelitian ini sejalan dengan teori uses and gratification yang digunakan. Responden cukup aktif memilih media dalam memenuhi kebutuhannya. Hal ini media tirto.id sebagai media yang menyajikan informasi serta berita cukup dalam memenuhi kebutuhan responden yang mencari informasi terkait Livi Zheng. terlihat dalam beberapa hal seperti, pertama penggunaan media yang terdiri jumlah waktu yang dihabiskan dalam mencari serta membaca berita di media tirto.id. Kedua, isi media tirto.id yang dilihat pada topik pemberitaan, kejelasan membahas berita serta kelengkapan atas sumber maupun data pendukung di setiap berita. Ketiga, tampilan akan media yang terlihat pada kemudahannya, fiturt-fitur yang ada, serta fitur tambahan seperti berbagi link berita dan kolom pencarian topik berita.
Berdasarkan hasil penelitian maka peneliti memberikan saran berupa:

1. Penelitian ini hanya meneliti penggunaan media tirto.id terhadap pemenuhan kebutuhan informasi terkait berita Livi Zheng kepada mahasiswa ilmu komunikasi UPNVJ, maka diharapkan kepada penelitian selanjutnya dapat mengkaji dan menguji lebih lanjut dengan menganalisis variabel lain yang dapat melihat nilai efektivitas penggunaan media tirto.id secara kuat. Selain itu diharapkan penelitian selanjutnya lebih memperbesar populasi sehingga menambah jumlah sampel dari penelitian ini.

2. Pihak media tirto.id bisa memberikan kebutuhan informasi lebih kuat dalam mengangkat berita, sehingga pembaca dapat menangkap dan memahami dengan baik topik berita yang diangkat. Harus bisa menyajikan informasi dengan benar dan tepat sesuai nilai jurnalistik terutama dalam mengangkat berita terkait Livi Zheng.

3. Mahasiswa ilmu komunikasi UPNVJ yang menjadi populasi dan sampel, bisa lebih aktif menggali informasi dan membacanya. Terlebih berita terkait Livi Zheng ataupun hal lain, baik dalam media tirto.id ataupun media lain.

\section{Saran}




\section{Daftar Pustaka}

\section{Buku}

Abdurrahman, Maman dan Sambas Ali. (2011). Panduan Praktis Memahami Penelitian

(Bidang Sosial-AdministrasiPendidikan). Bandung: CV Pustaka Setia.

Ardial. (2015). Paradigma dan Model Penelitian Komunikasi. Jakarta:

PT Bumi Aksara.

Ardianto, Elviano. Dkk. (2007).

Komunikasi Mass, Bandung: Simbiosa

Rekatama

Daryanto. (2011). Ilmu Komunikasi.

Bandung: PT. Sarana Tutorial Nurani

Sejahtera

Djuarsa Senjaya, Sasa dkk. (2007). Teori Komunikasi. Jakarta: Universitas Terbuka Fachrul Nurhadi, Zikri. (2017). Teori Komunikasi Kontemporer. Depok: Kencana

Elizabeth Goenawan Ananto. (2016). Metodologi Penelitian untuk Public Relation

Kuantitatif dan Kualitatif. Bandung: Simbiosa Rekatama Media.

K, Sepiawan Santana. (2005). Jurnalistik Kontemporer. Jakarta: Yayasan Obor Indonesia.

Kusumaningrat, Hikmat dan Purnama Kusumaningrat. (2005). Jurnalistik Teori dan Praktik.

Bandung: PT Remaja Rosdakarya.

Mondry, M.Sos. (2008). Pemahaman Teori dan Praktik Jurnalistik. Bogor: Ghalia Indonesia.

Mulyadi, Nadi dan Asti Musman. (2013). Jurnalisme Dasar Panduan Praktis Jurnalis. Yogyakarta: Citra Media.

Rakhmat, Jalaluddin. (2018). Psikologi Komunikasi Edisi Revisi. Bandung: Simbiosa
Rekatama Media.

Sudaryono. (2018). Metodologi Penelitian. Depok: PT RajaGrafindo Persada

Suhandang, kustadi. (2010). Pengantar Jurnalistik Seputar Organisasi, Produk \& Kode Etik.

Bandung: Nuansa.

Sumadiria, Haris. (2016). Jurnalistik Indonesia Menulis Berita dan Feature Panduan Praktis

Jurnalis Profesional. Bandung: Simbiosa Rekatama Media.

Suryabrata, Sumadi. (2013). Metodologi Penelitian. Jakarta: Rajawali Pers.

Suryawati, Indah. (2011). Jurnalistik Suatu Pengantar: Teori \& Praktik. Bogor: Ghalia Indonesia.

Suyanto, Bagong dan Sutinah. (2011). Metode Penelitian Sosial Berbagai Alternatif

Pendekatan Edisi Revisi. Jakarta: Kencana.

\section{Jurnal}

Harisanty, Dessy. (2007). Kebutuhan Informasi Siswa SMA dan Ketersediaan

Sumber Informasi pada Perpustakaan SMA di Surabaya

Puspitadewi, Isni dkk. (2016).

Pemanfaatan "Twitter

TMCPOLDAMETRO" Dalam

Memenuhi Kebutuhan Informasi Para Pengguna Jalan Raya. JKIP. Vol. 4/No. 1.

Riyanti, Rini dan Sherra Triarosdianan. 2015. Efektivitas Infografis Media Online (Survey Pemberitaan Tempo.co Pada Mahasiswa Perguruan Tinggi Swasta Kopertis Wilayah III). Bina Widya. Volume 26 Nomor 1. Maret 2015 


\section{Skripsi}

Arianti, Christ Violita. (2016). Pengaruh Penggunaan Google Search Engine dalam

Pemenuhan Kebutuhan Informasi

di Kalangan Mahasiswa (studi pada mahasiswa

$$
\text { program studi S1 Fakultas }
$$

Ekonomi dan Bisnis Universitas

Lampung). Lampung:

Universitas Lampung

Maharani, Christin. 2009. Penggunaan

Media dan Kepuasan Khalayak (Studi

Tentang Motif

Penggunaan Media Info Sukowati

Terhadap Kepuasan Dalam Membaca

Berita di

Media Internal Dalam Rangka

Pemenuhan Kebuuhan Informasi di

Kalangan

Sekretariat Daerah Kabupaten Sragen). Surakarta: Universitas Sebelas Maret.

\section{Website}

https://www.tagar.id/kronologi-klaim-

film-livi-zheng-didebat-joko-anwar/amp/ diakses pada diakses pada 20 September 2019 oleh Eno Dimedjo

https://tagar.id/livi-zheng-gadis-blitartembus-hollyword diakses pada 21 September 2019

https://www.kominfo.go.id/content/deta il/12345/menkominfo-baru-100-portalberita-onlineterverifikasi/0/berita satker diakses pada 21 September 2019 oleh anni005 kategori berita kementerian https://dewanpers.or.id/data/perusahaa npers diakses pada 21 September 2019 https://tirto.id/insider/redaksi 